\title{
TRANSFORMATIONAL LEADERSHIP ON EMPLOYEE'S PERFORMANCE: A STUDY OF GHANA COMMERCIAL BANK, CIRCLE AND LA BRANCHES-ACCRA
}

\author{
${ }^{1}$ David Mbotor Eleng, ${ }^{2}$ Daniel, Zachariah Abel, ${ }^{3}$ Chiamaka Deborah Odazie and \\ ${ }^{4}$ Enagu Tabe, A. \\ ${ }^{1}$ Department of Accountancy, Cross River University of Technology, Calabar \\ ${ }^{2}$ Department of Accounting, Federal University of Kashere, Gombe State \\ ${ }^{3}$ School of Business Studies, Zenith University College, Accra, Ghana \\ ${ }^{4}$ Department of Business Administration, Open University of Nigeria \\ Email: mbotormbotor@gmail.com
}

Corresponding author: David Mbotor Eleng B.Sc., M.Sc. (Acct), M.Sc. (Fin), MBA, ACCA, Ph.D (Acct) in view. Lecturer, Department of Accountancy, Cross River University of Technology, Calabar.

\begin{abstract}
The need to develop better leadership styles is becoming increasingly important in all organizations. With the changing demographics of today's workplace, the role of the manager/leader in the bank is ever evolving and the demands on their all-encompassing role ever increasing. This study aimed at examining the effect of transformational leadership on employee's performance, the case study of Ghana Commercial Bank, Circle and La Branches-Accra.

The study design was a descriptive survey. The study used a sample size of forty (40) respondents who were employees. Convenience sampling was used as the sampling technique. Structured self-administered questionnaires were adopted. Statistical Package for Social Sciences and descriptive statistics such as frequency tables and percentages were used in presenting and analyzing the data.

It was found that leader/manager encouraged employee's participation to contribute to the decision-making process. The findings clearly revealed that majority of the respondents stated that leadership style was properly and carefully used to guide and motivate employees. It was revealed that most of the owners prepare their financial reports at the end of the period. According to the findings, most of the employees want their managers to be a team player, encourage them to perform as well as attend to their problems. It is recommended that leaders should endeavor to adopt the best style suitable to deal with fellow employees. Hence, they should be adaptive, sincere, easy to talk to, straight forward, alert to happenings around, be open minded and most importantly be accommodating and supportive so that the staff would be happy in the discharge of their duties.
\end{abstract}

Keywords: Leadership, Performance, Employees, Transformational 


\subsection{Introduction}

The need to develop better leadership styles is becoming increasingly important in all organizations. Leadership style may be defined as a process whereby an individual influences a group of individuals to achieve a common goal (Northouse, 2007). Transformational leadership emphasizes the importance of leaders' relationships with followers. Key behaviors of transformational leaders include expressing a vision, making sense of missions, showing determination, and communicating high performance expectations (Conger \& Kanungo, 2007). The favorable effects of transformational leadership behavior on followers include producing followers' confidence in the leader, making followers feel good in the leader's presence, and obtaining strong admiration or respect from employees (Conger \& Kanungo2007).

Employee performance plays an essential role for organizational performance. Employee performance is initially what an employee does or does not do. Performance of employees could include quantity of output, quality of output, timeliness of output, presence at work, cooperativeness (Güngör, 2011). Mackay and Johnson (2001) pointed that improved individual employee performance could improve organizational performance as well. Effective organizations require both tactical and strategic thinking. Strategic thinking leadership style helps to create and build the vision as well as the performance of employees. Leaders/managers who articulate their views to employees typically display a sense of vision and purpose and empower them to take greater responsibility for achieving the vision. Such leadership style facilitates and teaches employees for their personal responsibility and development of their followers. Messick and Kramer (2004) said that the degree to which an individual exhibits leadership style depends not only on his characteristics and personal abilities, but also on the characteristics of the situation and environment in which he finds himself. Again, to be an effective leader or manager, a person needs to execute leadership styles interactions that are based on a sharing of insights, knowledge and responsibilities for achieved outcomes (Hitt \& Ireland, 1999).

These interactions occur between the employees and the stakeholders in an organization. One focuses on the tasks or performance of the firm, such as planning, articulating the vision or goals for the organization, monitoring subordinate activities, and providing necessary support, equipment and technical assistance. The other focuses on relationships with employees, including being supportive of and helpful to subordinates, showing trust and confidence in employees, being friendly and considerate, trying to understand subordinate's problems, showing appreciation for a subordinate's ideas, and providing recognition for subordinate's contributions and accomplishments (Yukl, 2002).

\subsection{Objective of the Study}

The general objective of the study is to examine effect of transformational leadership on employee's performance, the case study of Ghana Commercial Bank, Circle and La Branches-Accra. Specifically, to:

1. Examine transformational leadership and the extent to which it has affected employee performance at GCB (Ghana) Limited.

2. Examine the benefits of transformational leadership to employees.

3. Assess the challenges of employees with regards to transformational leadership at Ghana Commercial Bank. 


\subsection{Conceptual Review}

To fully expound on the enormous impact of transformational leadership on employee's performance, this study will analogize on the two most significant leadership theories in the field of social sciences. First, is the Leadership-Member-Exchange Theory (LMX). Research has found generally a relationship between LMX and positive work performance (Gerstner \& Day, 1997). The goal of leader-member exchange theory is to explain the effects of transformational leadership on staff members, teams, and the general management. And also the LMX theory is a relationship based approach to organizational leadership that focuses on the two-way (dyadic) relationship between leaders/managers and followers/subordinates. To stimulate high employee performance, the leader-member exchange creates an organizational climate of mutual respect for competence, trust in character and benevolence to each other (leader-member), leading to greater organizational performance. Gerstner \& Day, metaanalysis associate LMX with high performance rating, better objective performance, high overall satisfaction, more satisfaction with supervisor, strong organizational commitment, and more positive role perception.

The second theory was propounded by (Bernard M. Bass, 1985), which is known as the "Bass transformational Leadership theory." This theory helps explain how transformational leadership could be measured, as well as impacts on follower's motivation and performance. Bernard Bass theorized that the extent to which a leader is transformational is measured first, in terms of his influence on the followers. Transformational leadership is when the leader behaviors influence followers and inspire them to perform beyond their perceived capacities. Transformational leaders/managers inspire, motivate, support and enhance job performance by understanding the strengths and weaknesses of their followers/subordinates. Transformational leaders in organizations are managers who inspire people to achieve planned or unexpected and remarkable results. Transformational leaders inspire people through the strength of their vision and personality.

Objectively, both LMX theory and transformational leadership theory adopt the participative or democratic leadership style in organizations. Consensually, the democratic leadership style favors decision-making by the group, which makes organizational goals and objectives all abiding. While participative leadership style on the other hand encourages mutual respect, giving the employee a sense of belonging, thereby motivating them to go extra mile in order to achieve organizational goals and objectives which they now see as their personal responsibility. Transformational leadership as an organizational strategy works best in a decentralized or flat organizational structure. It gives workers the autonomy over specific jobs, as well as the authority to make decisions once they have been trained.

\subsubsection{Key Contemporary Leadership Traits that Spurs Employees Performance in Organization}

From centuries ago and even up till date there seems to be dozens of conflicting opinions over what traits, attributes or characteristics distinguishes one as a leader. Over the years different scholars have argued the efficacy and nature of such traits. To some scholars, these traits are heritable attributes that differentiate a leader from non-leader. These traits are also describing to be immutable and cannot be developed as opined by Thomas Carlyles and Francis Galton (1840), theorists of the "great man leadership theory." As opposed to the great man theory which posits that a leader is born and automatically possesses those traits that makes him a leader, other leadership scholars are of the opinion that leadership traits can be developed over time and through practice. 
Now, irrespective of the opposing views of both schools of thought, the underline traits, attributes and characteristics have been found to be consistent in every leader despite the changing situation:

- Strong vision

- Optimism

- Patriotism

- High assertiveness

- decisiveness

- Communication skills

- Interpersonal skills

- Management skills

- Self-confidence

- Cognitive ability

- Emotional stability

- Honesty/integrity

Cultivating and developing these aforementioned traits is a crucial part of becoming a transformational leader that inspires people to achieve personal and organizational goals and objective, going further to spur high performance and employee satisfaction with self-and the management.

\subsection{Methodology}

The survey research design was adopted for the study with a well-structured questionnaire issued to the staff of Ghana commercial bank. The sample for the study was the employees of GCB Limited from Osu, Circle and La Branches-Accra. Investigation conducted by us from the branches shows that total numbers of employees from the respective branches of the bank were 24 respondents from Osu, 20 from Circle branch and 16 from Labadi branch constituting 60 .

\subsection{Data Presentation and Analysis}

Questionnaires issued out had 40 successfully collected, 3 inappropriately filled and 17 not returned.

The study collected information on the demographic characteristics of respondents. Detailed results on each of the demographic characteristics of the respondents are presented.

Table 1: Gender of respondents

\begin{tabular}{lccc}
\hline Gender & Frequency & Percentage (\%) \\
\hline Male & & 15 & 38 \\
Female & & 25 & 62 \\
& & & \\
\hline Total & $\mathbf{4 0}$ & $\mathbf{1 0 0}$ & \\
\hline
\end{tabular}

Source: Field Study, 2017 
Table 1 above shows the demographic distribution of respondents. According to the gender distribution of respondents, 15 which represented $38 \%$ of the total respondents are male while the female respondents are 25 which represented $62 \%$. This means that there is female dominant staff among workers at the bank.

Table 2: Age of respondents

\begin{tabular}{lcc}
\hline Age & Frequency & Percentage (\%) \\
\hline $18-25 y r s$ & 2 & 5 \\
$26-33 y r s$ & 11 & 27 \\
$34-41$ yrs & 19 & 48 \\
42 years and above & 8 & 20
\end{tabular}

\begin{tabular}{lll}
\hline Total & 40 & 100
\end{tabular}

Source: Field Study, 2017

Also from the age group distribution of respondents, Table 2 shows that two which represented (5\%) employees were between the ages of $18-25$ years, 11 which denoted $27 \%$ were between the age ranges of 26-33 years, 19 which signify $48 \%$ were between the ages of $34-41$ years whiles eight which represented $20 \%$ of the respondents were 42 years and above. The result showed that, the bank has a relatively matured workforce as the majority of the employees were between the ages of $34-41$ years of age.

Table 3: Respondents educational level

\begin{tabular}{lll}
\hline Educational Background & Frequency & Percentage (\%) \\
\hline Professional Certificate & 2 & 5 \\
Diploma & 9 & 22 \\
HND & 7 & 18 \\
First Degree & 16 & 40 \\
Master's Degree & 6 & 15 \\
\hline Total & $\mathbf{4 0}$ & $\mathbf{1 0 0}$ \\
\hline
\end{tabular}

Source: Field Study, 2017

According to the educational qualification of respondents, Table 4.3 shows that two which represented 5\% of employees were Professional Certificate holders, nine which represented 22\% were Diploma holders, seven which represented 18\% were HND holders whiles sixteen which represented $40 \%$ were first degree holders, six which represented $15 \%$ were Master's Degree holders. The results showed that most of the respondents were first degree holders hence understood the information sought by this study. 
Article DOI: 10.46654/ij.24889849.s61014

Table 4: Working experience of the respondents

\begin{tabular}{lll}
\hline Tenure & Frequency $(\mathrm{N})$ & Percentage $(\%)$ \\
\hline Less than 1 year & 6 & 15 \\
1-3 years & 16 & 40 \\
3-5years & 8 & 20 \\
5 years above & 10 & 25 \\
\hline Total & $\mathbf{4 0}$ & $\mathbf{1 0 0}$
\end{tabular}

Source: Field Study, 2017

The respondents were asked to indicate the length they had been with the bank and their response showed that, six which represented $15 \%$ of the employees of the bank had worked for 1 year or less, 16 which represented $40 \%$ had worked for 1-3 years, eight which represented $20 \%$ had worked for 3-5 years whiles 10 which represented $25 \%$ of employees had worked for above 5 years. It can be observed that majority of the employees had been with bank for long and hence understood the information sought by this study.

Section B: Leader/managers leadership style and employee performance

Table 5: Decision making process

\begin{tabular}{lll}
\hline Descriptions & Frequency $(\mathrm{N})$ & Percentage $(\%)$ \\
\hline Strongly agree & 10 & 25 \\
Agree & 12 & 30 \\
Undecided & 8 & 20 \\
Disagree & 6 & 15 \\
Strongly Disagree & 4 & 10 \\
\hline Total & $\mathbf{4 0}$ & $\mathbf{1 0 0}$ \\
\hline
\end{tabular}

Source: Field Study, 2017

Table 5 shows that, 10 which represented $25 \%$ and 12 which represented $30 \%$ of the respondents believed that their leader/manager encourage employee's participation to contribute to the decision-making process. Six which represented(15\%) disagreed with the assertion, four which represented $10 \%$ strongly disagreed as well as eight which represented $20 \%$ were not sure. This implied that most of the respondents believed their leader/manager encouraged employee's participation to contribute to the decision-making process. 
Article DOI: 10.46654/ij.24889849.s61014

Table 6: Brainstorming and discussion

\begin{tabular}{lll}
\hline Descriptions & Frequency $(\mathrm{N})$ & Percentage (\%) \\
\hline Strongly agree & 8 & 20 \\
Agree & 14 & 35 \\
Undecided & 7 & 17 \\
Disagree & 6 & 15 \\
Strongly Disagree & 5 & 13 \\
\hline Total & $\mathbf{4 0}$ & $\mathbf{1 0 0}$
\end{tabular}

Source: Field Study, 2017

From the Table 6, 14 which represented $35 \%$ of the respondents agreed that the leader/manager makes the final decisions to get employees involved in brainstorming and discussion. Six of them which represented $15 \%$ disagreed with the statement and seven which represented $35 \%$ were neutral. This implied that the leader/manager made the final decisions to get employees involved in brainstorming and discussion.

Table 7: Achieve desired results

\begin{tabular}{lll}
\hline Descriptions & Frequency (N) & Percentage (\%) \\
\hline Strongly agree & 8 & 20 \\
Agree & 17 & 43 \\
Undecided & 7 & 17 \\
Disagree & 5 & 13 \\
Strongly Disagree & 3 & 7 \\
\hline Total & $\mathbf{4 0}$ & $\mathbf{1 0 0}$ \\
\hline
\end{tabular}

Source: Field Study, 2017

Table 7 shows that, 17 which represented $43 \%$ of the respondents agreed that the leader/managers display enthusiasm to subordinates in an effort to inspire them to achieve desired results. Five of them which represented 13\% disagreed with the statement and seven which represented $17 \%$ were neutral. It can be deduced that the leader/manager exuded enthusiasm for subordinates in an effort to inspire them to achieve desired results. 
Article DOI: 10.46654/ij.24889849.s61014

Table 8: Empower subordinates individually

\begin{tabular}{lll}
\hline Descriptions & Frequency $(\mathrm{N})$ & Percentage (\%) \\
\hline Strongly agree & 7 & 17 \\
Agree & 14 & 35 \\
Undecided & 10 & 25 \\
Disagree & 4 & 10 \\
Strongly Disagree & 5 & 13 \\
\hline Total & $\mathbf{4 0}$ & $\mathbf{1 0 0}$
\end{tabular}

Source: Field Study, 2017

Table 8 shows that, 14 which represented $35 \%$ of the respondents agreed that the leader/manager works diligently to empower subordinates individually. A total of 4 respondents represented $10 \%$ disagreed with the statement and 10 which represented $25 \%$ were neutral. It can be observed that the leader/manager works diligently to empower subordinates individually.

\section{Section C: Benefits of leadership style to employees}

Table 9: Considerable influence on the work performance

\begin{tabular}{lll}
\hline Descriptions & Frequency $(\mathrm{N})$ & Percentage $(\%)$ \\
\hline Strongly agree & 8 & 20 \\
Agree & 17 & 43 \\
Undecided & 6 & 15 \\
Disagree & 5 & 12 \\
Strongly Disagree & 4 & 10 \\
\hline Total & $\mathbf{4 0}$ & $\mathbf{1 0 0}$
\end{tabular}

Source: Field Study, 2017

Table 9 shows that, 17 which represented $43 \%$ of the respondents agreed that the leadership style of a leader has a considerable influence on the work performance of employees. Five of them which represented $12 \%$ disagreed with the statement and six which represented $15 \%$ were neutral. It can be implied that the leadership style of a leader has a considerable influence on the work performance of employees. 
Article DOI: 10.46654/ij.24889849.s61014

Table 10: Role tasks and positions

\begin{tabular}{lll}
\hline Descriptions & Frequency $(\mathrm{N})$ & Percentage (\%) \\
\hline Strongly agree & 7 & 17 \\
Agree & 19 & 48 \\
Undecided & 8 & 20 \\
Disagree & 2 & 5 \\
Strongly Disagree & 4 & 10 \\
\hline Total & $\mathbf{4 0}$ & $\mathbf{1 0 0}$
\end{tabular}

Source: Field Study, 2017

Table 10 shows that, 19 which represented $48 \%$ of the respondents agreed that their manager defines role tasks and positions of employees to improve performance. Two of them which represented 5\% disagreed with the statement and eight which represented $20 \%$ were neutral. The outcome showed that most of the employees believed that their leader/manager defines role tasks and positions of employees to improve performance.

Table 11: Guidance and motivation to employees

\begin{tabular}{lll}
\hline Descriptions & Frequency $(\mathrm{N})$ & Percentage (\%) \\
\hline Strongly agree & 8 & 20 \\
Agree & 13 & 32 \\
Undecided & 10 & 25 \\
Disagree & 6 & 15 \\
Strongly Disagree & 3 & 8 \\
\hline Total & $\mathbf{4 0}$ & $\mathbf{1 0 0}$
\end{tabular}

Source: Field Study, 2017

Table 10 shows that, 13 which represented $32 \%$ of the respondents agreed that transformational leaders are properly and carefully used to guide and motivate employees. Six of them which represented $15 \%$ disagreed with the statement and 10 which represented $25 \%$ were neutral. It can be deduced that transformational leaders were properly and carefully used to guide and motivate employees. 
Article DOI: 10.46654/ij.24889849.s61014

Table 12: Suggestions and feedback to work execution

\begin{tabular}{lll}
\hline Descriptions & Frequency $(\mathrm{N})$ & Percentage (\%) \\
\hline Strongly agree & 6 & 15 \\
Agree & 20 & 50 \\
Undecided & 7 & 17 \\
Disagree & 3 & 8 \\
Strongly Disagree & 4 & 10 \\
\hline Total & $\mathbf{4 0}$ & $\mathbf{1 0 0}$
\end{tabular}

Source: Field Study, 2017

Table 12 shows that, 20 which represented $50 \%$ of the respondents agreed that the leader/manager determines the organizational performance that subordinates need realize, and gives suggestions and feedback to execution. Three of them which represented $8 \%$ disagreed with the statement and seven which represented $25 \%$ were neutral. It can be observed that the leader/manager determines the organizational performance that subordinates need realize, and gives suggestions and feedback to execution.

\section{Section D: Challenges of employees with regards to the leadership style}

Table 13: Friendly and approachable

\begin{tabular}{lll}
\hline Descriptions & Frequency $(\mathrm{N})$ & Percentage (\%) \\
\hline Strongly agree & 6 & 15 \\
Agree & 16 & 40 \\
Undecided & 6 & 15 \\
Disagree & 7 & 17 \\
Strongly Disagree & 5 & 13 \\
\hline Total & $\mathbf{4 0}$ & $\mathbf{1 0 0}$ \\
\hline
\end{tabular}

Source: Field Study, 2017

Table 13 shows that, 16 which represented $40 \%$ of the respondents agreed that they want their mangers to be friendly and approachable to their fellow employees. Seven of them which represented $17 \%$ disagreed with the statement and six which represented $15 \%$ were neutral. It can be implied that most of the employees want their leader/manager to be friendly and approachable to their fellow employees. 
Article DOI: 10.46654/ij.24889849.s61014

Table 14: Expression of opinion

\begin{tabular}{lll}
\hline Descriptions & Frequency $(\mathrm{N})$ & Percentage $(\%)$ \\
\hline Strongly agree & 5 & 12 \\
Agree & 18 & 45 \\
Undecided & 8 & 20 \\
Disagree & 6 & 15 \\
Strongly Disagree & 3 & 8 \\
\hline Total & $\mathbf{4 0}$ & $\mathbf{1 0 0}$
\end{tabular}

Source: Field Study, 2017

Table 14 shows that, 18 which represented $45 \%$ of the respondents agreed thatthey want their leader/manager to allow them to express their views openly. Six of them which represented $15 \%$ disagreed with the statement and eight which represented $20 \%$ were neutral. It can be deduced that the most of the employees want their leaders/managers to allow them to express their views openly.

Table 15: Team player

\begin{tabular}{lll}
\hline Descriptions & Frequency $(\mathrm{N})$ & Percentage (\%) \\
\hline Strongly agree & 7 & 17 \\
Agree & 12 & 30 \\
Undecided & 10 & 25 \\
Disagree & 6 & 15 \\
Strongly Disagree & 5 & 13 \\
\hline Total & $\mathbf{4 0}$ & $\mathbf{1 0 0}$
\end{tabular}

Source: Field Study, 2017

Table 15 shows that, 12 which represented $30 \%$ of the respondents agreed that they want their leader/manager to be a team player. Six of them which represented $15 \%$ disagreed with the statement and ten which represented $25 \%$ were neutral. It can be observed that most of the employees want their leaders/managers to be a team player. 
Table 16: Encouragement to perform

\begin{tabular}{lll}
\hline Descriptions & Frequency $(\mathrm{N})$ & Percentage (\%) \\
\hline Strongly agree & 10 & 25 \\
Agree & 12 & 30 \\
Undecided & 8 & 20 \\
Disagree & 6 & 15 \\
Strongly Disagree & 4 & 10 \\
\hline Total & $\mathbf{4 0}$ & $\mathbf{1 0 0}$
\end{tabular}

Source: Field Study, 2017

Table 16 shows that, 12 which represented $30 \%$ of the respondents agreed that they want their leader/manager to encourage them to perform. Six of them which represented $15 \%$ disagreed with the statement and eight which represented $20 \%$ were neutral. It can be observed that most of the employees want their leaders/managers to encourage them to perform.

\section{Table 17: Attendance to problems}

\begin{tabular}{lll}
\hline Descriptions & Frequency $(\mathrm{N})$ & Percentage $(\%)$ \\
\hline Strongly agree & 8 & 20 \\
Agree & 14 & 35 \\
Undecided & 7 & 17 \\
Disagree & 6 & 15 \\
Strongly Disagree & 5 & 13 \\
\hline Total & $\mathbf{4 0}$ & $\mathbf{1 0 0}$ \\
\hline
\end{tabular}

Source: Field Study, 2017

Table 17 shows that, 14 which represented $35 \%$ of the respondents agreed that they want their managers to attend to their problems, eight which represented $20 \%$ strongly agreed, while six which represented $15 \%$ disagreed. However, five which represented $13 \%$ strongly disagreed with the statement and seven which represented $35 \%$ were neutral. This implied that employees want their managers to attend to their problems.

\subsection{Discussion of Results}

The main objective of the study is to examine effect of transformational leadership on employee's performance, the case study of Ghana Commercial Bank. The first objective examined transformational leadership and the extent to which it has affected employee performance at GCB (Ghana) Limited. It was found that most of the respondents believed leader/manager encouraged employee's participation to contribute to the decision-making process. Findings indicate that the leader/manager makes the final decisions to get employees involved in brainstorming and discussion. The research revealed that the leader/manager 
exudes enthusiasm within his subordinates in an effort to inspire them to achieve desired results. Findings of the study revealed that the leader/manager worked diligently to empower subordinates individually.

The second objective examined the benefits of transformational leadership to employees. The study revealed that the leadership style of a leader has a considerable influence on the work performance of employees. Findings from the study indicated that most of the employees believed that their manager defines role tasks and positions of employees to improve performance. The study revealed that transformational leaders were properly and carefully used to guide and motivate employees. The findings also revealed that, the leader/manager leadership style gives room for employees' suggestions and feedback to execute work.

The third objective assesses the challenges of employees with regards to transformational leadership at Ghana Commercial Bank. Findings from the study indicated the most of the employees want their leaders/mangers to be friendly and approachable to their fellow employees. The study further revealed that most of the employees want their leaders/managers to allow them to express their views openly. It was observed that most of the employees want their leaders to be a team player, encourage them to perform as well as attend to their problems.

\subsection{Conclusion /Recommendation}

The study concluded that the leader/manager encouraged employee's participation to contribute to the decision-making process. It can also be concluded that the leader/manager makes the final decisions to get employees involved in brainstorming and discussion. Further to this, the leader/manager exudes enthusiasm within his subordinates in an effort to inspire them to achieve desired results. It can be concluded that the leader/manager works diligently to empower subordinates individually. The leadership style of a leader has a considerable influence on the work performance of employees and that most of the employees believed that their manager defines role tasks and positions of employees to improve performance. The study further concluded that leadership style was properly and carefully used to guide and motivate employees. The findings from the study also concluded that the leader's/manager's leadership style gives room for employees' suggestions and feedback to execute work. It is recommended that managers/leaders should endeavor to adopt the best style suitable to deal with fellow employees. Hence, they should be adaptive, sincere, easy to talk to, straightforward, alert to happenings around them, open minded and most importantly be accommodating and supportive so that the staff would be happy in the discharge of their duties. Leadership development program for managers at all level of the organization should be prioritized, as a way of expanding their leadership and managerial capacity to perform optimally in leadership roles within and outside the organization. 


\section{References}

Carlyle, Thomas (1840). On heroes, Hero-worship, and The Heroic in History: Carlyle collected works. London: Chapman and Hall (published 1841) Reviews 2014.

Gerstner, Charlotte R., \& Day, David V. (1997) "Meta-Analysis Review of Leader-Member Exchange Theory: Correlates and Construct Issues. Journal of Applied Psychology (6), 827-844.

Gungor, A. (2011). Communication with employees following a merger: A longitudinal experiment. Academy of Management Journal, 34, 110-35.

Hitt, W. S., \& Ireland, D. J. (1999). Individualized leadership: A new multiple-level approach. Leadership Quarterly, 6(3), 413-450.

Mackay, D. J., \& Johnson, F. M. (2001). Maintenance communication is superior-subordinate work relationships. Human Communication Research, 22, 220-257.

Messick, S., \& Kramer, A. P. (2004). Measuring charisma: Dimensionality and validity of the Conger-Kanungo scale of charismatic leadership. Canadian Journal ofAdministrative Sciences, 14 (3), 290-302.

Northouse, P.G, 2007. Leadership: Theory and practice. London: Sage publications. 